\title{
Effect of Olive Cake Pulp as A Partial or A Complete Substitute of Wheat Bran in Growing Rabbits' Diet on Growth Performance, Carcass Traits and Blood Constituents under North Sinai Conditions \\ Bakr, E. O. A. ${ }^{1}$; M. M. Shetaewi ${ }^{1}$ and A. El. M. I. El-Desoky ${ }^{2}$ \\ ${ }^{1}$ College of Environmental Agricultural Sciences, ArishUniversity, Al-Arish, North Sinai, Egypt \\ ${ }^{2}$ Anim. Prod. Res. Inst., Agric. Res. Center, Dokki, Giza, Egypt.
}

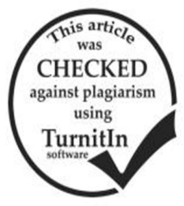

\section{ABSTRACT}

Sixty weaned New Zealand white rabbits of both sexes aged $6 \mathrm{wk}$ and weighed $715 \mathrm{~g}$ were randomly divided into four treatment groups (15 rabbits each) to evaluate the possibility of feeding growing rabbits on diets containing olive cake pulp (OCP) as partial or complete substitution of wheat bran. The first group $(\mathrm{C})$ was fed the basal diet as control $(0 \% \mathrm{OCP})$, while the other three treatment groups $(\mathrm{L}, \mathrm{M}, \mathrm{H})$ were fed diets containing 15,20 and $25 \% \mathrm{OCP}$, respectively replacing wheat bran in the basal diet. All the experimental diets contained nearly the same level of crude protein $(\mathrm{CP})$ and digestible energy (DE). All the experimental diets were formulated to cover the nutrient requirements of rabbits. Results revealed that dietary treatments had no significant effect on live body weight (LBW), total weight gain (TWG), average daily gain (ADG) and daily fed intake (DFI) at different ages (6-14 wk). At the same time, LBW, TWG and ADG tended to be higher in rabbits fed $\mathrm{M}$ and $\mathrm{H}$ diets than those fed $\mathrm{C}$ and $\mathrm{L}$ diets. Daily feed intake of the $\mathrm{L}$ group tended to be lower $(\mathrm{P}>0.05)$ than that of the other groups $(\mathrm{C}, \mathrm{M}$ and $\mathrm{H})$. Feed conversion of $\mathrm{H}$ group was the best compared with the other groups $(\mathrm{C}, \mathrm{L}$ and $\mathrm{M}$ groups). Glucose and triglycerides levels in blood serum of rabbits decreased significantly $(\mathrm{P}<0.05)$ due to treatment. However, serum total protein, albumin, globulin, Alb/Glo, cholesterol, urea, creatinine, AST and ALT were not affected significantly $(\mathrm{P}>0.05)$ by treatment. Almost carcass traits (empty carcass, edible giblets and dressing) were not affected $(\mathrm{P}>0.05)$ by treatment. From the economic point of view, it appears that the inclusion of OCP in growing rabbit diets by $15,20,25 \%$ instead of wheat bran as fed basis decreased feed cost/ $\mathrm{kg}$ gain by $9.11,7.25$ and $14.32 \%$, respectively. The economic efficiency values of the experimental diets were increased by $23.88,20.15$ and $26.73 \%$, respectively compared with the control diet. In conclusion, olive cake pulp (OCP) could be incorporated in growing rabbits diets up to $25 \%$ without adverse effects on growth performance, carcass traits, blood constituents and economic efficiency.

Keywords: Rabbits, olive cake pulp, productive performance, carcass traits, blood constituents, economic efficiency.

\section{INTRODUCTION}

In some developing countries, rabbits are considered a good source for meat production because of their high reproductive rates, short generation period, rapid growth rates, high feed efficiency and simple housing requirements. Also, they can be fed a diet containing fibrous by-products (Aboul-Ela et al., 2011). These fibers play a role in maintaining micro-ecological balance of the gut, promoting digestive system development and raising reproductive performance of rabbits (GU, 2002). The acute shortage of energy sources and their increasing costs are the main limiting factors for improving and increasing animal production. Therefore, many efforts to find economical energy sources that are less competitive with human foods have been intensified. Using agro-industrial by-products such as olive cake pulp in animal diets may participate in solving the problem of energy sources shortage, decrease the feeding cost and hence marketing price of animal products and alleviate pollution problems.

Olive cake pulp (OCP) as agro-industrial byproduct has been demonstrated by many investigators as an energy source for rabbits (EL-Kerdawy, 1997; AbdelNaby, 1998; EL-Sayed, 2010 and Mehrez and Mousa, 2011). In North Sinai, olive cake pulp represents the majority of agro-industrial by-products. About 35000 ton of olive fruits are annually produced and about 3000 ton olive cake pulp remain after oil extraction (North Sinai governorate, 2000). The operation of olive oil extraction is seasonal, starts from September to November. Each 1000 $\mathrm{kg}$ of fresh olive fruits produce $214 \mathrm{~kg}$ olive oil, $496 \mathrm{~kg}$ crude olive cake and $40 \mathrm{~kg}$ of leaves (V. Christodoulou et al., 2008). Olive cake pulp is a moderate protein and ether extract source, but it is a high crud fiber source. It contains from 8 to $10 \%$ protein (EL-Kerdawy, 1997; Abdel Samee et al., 2003; Abd EL-Galil, 2001; Rabayaa et al., 2001 and Mehrez and Mousa, 2011). It contains about 9 to $18 \%$ ether extract and about 18.5 to $33 \%$ crud fiber (ELKerdawy, 1997; EL-Sayed, 2010 and Mehrez and Mousa, 2011). The feeding values of olive cake pulp (as-fed basis) are $46.48 \%$ TDN, $40.33 \%$ S.V and $8.56 \mathrm{MJ} \mathrm{DE} / \mathrm{g}$ (Ghazalah and EL-Shahat, 1994). Also, EL-Lathy (2001) showed that DE of olive cake pulp was $3654 \mathrm{kcal} / \mathrm{kg}$. Many investigators studied the effects of different levels of olive cake pulp (up to $30 \%$ ) in rabbit diets on growth performance and feed efficiency (EL-Kerdawy, 1997; Abdel-Naby, 1998; EL-Sayed, 2010; Aboul-Ela et al., 2011 and Mehrez and Mousa, 2011). Their results showed that inclusion of OCP up to $25 \%$ in rabbit diets did not greatly affect either body weight changes or feed efficiency and had no effect on carcass traits.

The objective of this study was to investigate the effects of a partial or complete substitution of wheat bran by olive cake pulp in growing rabbit diets on growth performance, biochemical changes of the blood, carcass traits and economic efficiency.

\section{MATERIALS AND METHODS}

This study was carried out for 8 wk during the period from April to June 2015 at the rabbitry farm, Department of Animal and Poultry Production, Faculty of Environmental Agricultural Sciences, Arish University, North Sinai, Egypt.

The olive cake pulp was collected during the olive pressing season from September to November 2014. Olive cake pulp was spread on a plastic sheath for sun-drying until its content of moisture roughly reached $10 \%$.

Separation of stones was performed using a $2 \mathrm{~mm}$ sieve where big particles of stones were removed. Partly stoned olive cake pulp (OCP) obtained was stored in bags until it was used and sample of (OCP) was analyzed for crude protein $(\mathrm{CP})$, crude fibre $(\mathrm{CF})$, ether extract $(\mathrm{EE})$, 
ash, calcium (Ca) and phosphorus (P) according to A.O.A.C. (2012).

Feeding and Management. Sixty weaned New Zealand White (NZW) rabbits (6 wk old, 715 g body weight) were randomly allocated into 4 similar groups (15 rabbits each). The experimental period lasted for 56 days (from 6 to 14 wk of age). The first group (Control, C) was fed a pelleted control diet, while the other three groups (L, $\mathrm{M}$ and $\mathrm{H}$ ) were fed diets containing 15, 20 and $25 \%$ of OCP to substitute 60,80 and $100 \%$ of the wheat bran in the control diet, respectively (Table 1). OCP was mixed with feed ingredients and then the experimental diets under temperature of $65-70^{\circ}$ were pelleted at $0.4 \mathrm{~cm}$ diameter and $2 \mathrm{~cm}$ length. The experimental diets were formulated to be iso-nitrogenous $(17 \% \mathrm{CP})$ and iso-caloric $(2500 \mathrm{kcal} \mathrm{DE} / \mathrm{kg}$ diet). Diets were formulated to meet the recommended nutrient requirement of growing rabbits according to Agriculture Ministry Decree (1996). The composition of the experimental diets is presented in Table 1.

Rabbits were housed in galvanized wire cages measured $(40 * 40 * 30 \mathrm{~cm})$ in a well-ventilated building (natural through the window). The growing rabbits were housed as three in each cage. Cages were provided with feeders and automatic nipple drinkers.

Diets were offered to rabbits ad libitum and fresh water was available all the time. Urine and feces dropped from cages on the floor were cleaned every day in the morning. All rabbits were kept under the same managerial, hygienic and environmental conditions. All rabbits were individually weighed at the start of the experiment (6 wk of age) and weekly thereafter until marketing age (14 wk).

Weighing was done before offering the morning meal and feed consumption was recorded weekly. Body weight gains, feed conversion ( $g$ feed $/ g$ gain) and economic efficiency were calculated.

Carcass Traits. At the end of the experimental period (14 wk of age), three rabbits were randomly chosen from each treatment to study carcass traits. Rabbits were kept off feed overnight and body weights were recorded next morning prior to slaughter. After bleeding and skinning were completed, the carcass was opened down and all entrails were removed. The empty carcass with head, liver, kidneys and heart were weighed separately (Cheeke, 1987) and were calculated as percentage of live body weight at slaughtering.

Blood Constituents: At the end of the experimental period, individual blood samples from the same slaughtered rabbits were collected in dry clean centrifuge tubes and allowed to clot at room temperature for $30 \mathrm{~min}$. Serum was then separated by centrifugation at $3000 \mathrm{rpm}$ for $15 \mathrm{~min}$ and was subsequently decanted into glass vials and stored at $-20 \dot{\mathrm{C}}$ until it was analyzed. Serum total protein and glucose were colorimetrically determined using Kits supplied by Bio-merleux, France. Urea and creatinine colorimetrically determined using Kits supplied by Diamond, Egypt. Albumin, ALT and AST were colorimetrically determined using Kits supplied by Randox, England. Serum globulin was obtained by difference (Total protein minus albumin) and albumin/globulin (Alb/Glob) ratio was calculated. Cholesterol and triglycerides were colorimetrically determined using Kits supplied by Spectrum, Egypt.
Table 1. Composition and calculated analysis of the experimental diets.

\begin{tabular}{|c|c|c|c|c|}
\hline \multirow{2}{*}{ Item } & \multicolumn{4}{|c|}{ Dietary Treatment $^{1}$} \\
\hline & C & $\mathbf{L}$ & M & $\mathbf{H}$ \\
\hline \multicolumn{5}{|l|}{ Ingredients \% } \\
\hline Alfalfa hay $(12 \% \mathrm{CP})$ & 32 & 25 & 22 & 20 \\
\hline Yellow corn & 10 & 12 & 12 & 10 \\
\hline Barley & 15 & 17 & 18 & 21 \\
\hline Soya bean meal (44\% CP) & 12 & 15 & 17 & 18 \\
\hline Wheat bran & 25 & 10 & 5 & - \\
\hline Olive cake pulp (OCP) & - & 15 & 20 & 25 \\
\hline Molasses & 3 & 3 & 3 & 3 \\
\hline Salt & 0.3 & 0.3 & 0.3 & 0.3 \\
\hline Limestone & 1.2 & 1.2 & 1 & 1 \\
\hline Vitamins and mineral mixture $^{2}$ & 0.3 & 0.3 & 0.3 & 0.3 \\
\hline Di-calcium phosphate & 1.2 & 1.2 & 1.4 & 1.4 \\
\hline Total & 100 & 100 & 100 & 100 \\
\hline \multicolumn{5}{|l|}{ Calculated analysis ${ }^{3}:$} \\
\hline Digestible energy $(\mathrm{DE})^{4} \mathrm{kcal} / \mathrm{kg}$ & 2540 & 2480 & 2470 & 2440 \\
\hline Crude protein $(\mathrm{CP}), \%$ & 17.30 & 17.45 & 17.80 & 17.91 \\
\hline Crude fiber (CF),\% & 12.41 & 14.17 & 14.68 & 15.44 \\
\hline NDF, $\%$ & 37.77 & 38.23 & 38.57 & 39.07 \\
\hline Ether extract (EE), \% & 2.800 & 4.650 & 5.251 & 5.810 \\
\hline Calcium (CA), $\%$ & 1.260 & 1.240 & 1.206 & 1.205 \\
\hline Phosphorus (P), \% & 0.764 & 0.600 & 0.587 & 0.534 \\
\hline Available phosphorus, $\%$ & 0.465 & 0.380 & 0.392 & 0.365 \\
\hline Lysine, $\%$ & 0.849 & 0.800 & 0.800 & 0.790 \\
\hline Methionine, $\%$ & 0.290 & 0.230 & 0.210 & 0.193 \\
\hline $\mathrm{DE}: \mathrm{CP}$ & 158.0 & 159.9 & 157.9 & 157.2 \\
\hline Price $/ \mathrm{kg} \operatorname{diet}^{5}$ & 2.440 & 2.300 & 2.280 & 2.240 \\
\hline
\end{tabular}

${ }^{1}$ Dietary Treatment; $\mathbf{C}=$ Control, containing no OCP; $\mathrm{L}=$ containing $15 \%$ OCP; $M=$ containing $20 \%$ OCP; $H=$ containing $25 \%$ OCP\%.

${ }^{2}$ Vitamens and Min. mixture per kg contains: 12000 IU Vit. A; 2200 IU D3; 10mg Vit. E; 2.0 mg Vit. K3; 1.0 mg Vit. B1; 4.0 mg Vit.B2; $1.5 \mathrm{mg}$ Vit. B6; $0.0010 \mathrm{mg}$ Vit. B12; $6.7 \mathrm{mg}$ Vit. Pantothenic acid; $6.67 \mathrm{mg}$ Vit. B5; $1.07 \mathrm{mg}$ Biotin; $1.67 \mathrm{mg}$ folic acid; $400 \mathrm{mg}$ Choline chloride; $22.3 \mathrm{mg} \mathrm{Zn;} 10 \mathrm{mg} \mathrm{Mn;} 25 \mathrm{mg}$ Fe; $1.67 \mathrm{mg} \mathrm{Cu} 0.25 \mathrm{mg} \mathrm{I}$; $0.033 \mathrm{mg}$ Se and $133.4 \mathrm{mg} \mathrm{Mg}$.

${ }^{3}$ According to MOA 2001

${ }^{4}$ Calculated according to Cheeke (1987): DE $(\mathrm{kcal} / \mathrm{g})=4.36-0.0491$ (\%NDF).

$\%$ NDF $=28.924+0.657(\% \mathrm{CF})$.

${ }^{5}$ According to price of feed ingredients (2015).

Economic Efficiency (EE): The EE is defined as the net revenue per unit feed cost calculated from input output analysis as described by Abd EL-Maksoud (2011). The EE was calculated according to prices of feed and live body weight of rabbits (2015) as follows :

Feed cost $=$ total feed intake $(\mathrm{kg}) /$ rabbit * price of $\mathrm{kg}$ feed (LE)

Selling revenue $=$ Body weight gain $/$ rabbit $*$ price of $\mathbf{~ k g}$ for live body weight

Net revenue $=$ Difference between selling revenue and feed cost

Economic efficiency $=($ Net revenue $/$ total feed cost)*100

Relative economic efficiency (R. E. E), assuming control group $=\mathbf{1 0 0}$

Statistical analysis: The collected data were statistically analyzed by One-Way analysis of variance. Data were analyzed using SPSS 16.0 software for windows (2007). The results were reported as mean \pm standard error. Differences between treatment means were determined by Duncan's method (1955). Difference were considered significance at $p<0.05$. 


\section{RESULTS AND DISCUSSION}

Chemical Composition of Olive Cake Pulp (as- fed):

Chemical analysis of olive cake pulp (as - fed) is presented in Table 2. The OCP contained 90.7\% DM, $85.5 \%$ OM, $12.65 \%$ CP, $16.76 \%$ EE, $30.68 \%$ CF, $25.41 \% \mathrm{NFE}$ and $5.2 \%$ ash. Values of $\mathrm{CP} \%, \mathrm{CF} \%$ and $\mathrm{EE} \%$ of olive cake pulp in these study were higher than those obtained by Abd EL-Galil (2001), Rabayaa et al. (2001) and Mehrez and Mousa (2011). This may be due to the type of olive, stage of maturity of the fruits, the method of oil extraction and the environmental conditions (local of plantation).

Table 2. Chemical composition of olive cake pulp (asfed).

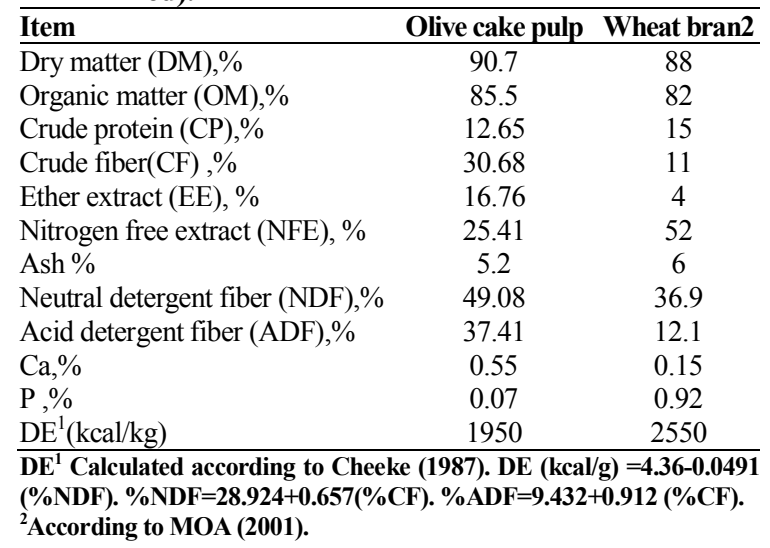

\section{Growth Performance and Feed Efficiency:}

Data presented in Table 3, showed that live body weight, total weight gain and daily weight gain of growing rabbits at different ages did not differ significantly due to treatment. Live bod weight at $14 \mathrm{wk}$ of age and total weight gain at 10-14 wk and at $14 \mathrm{wk}$ of age of rabbits of $\mathrm{M}$ and $\mathrm{H}$ treatment groups were improved slightly $(\mathrm{P}>.05)$ compared with those of $\mathrm{C}$ or $\mathrm{L}$ groups. Average daily gain (ADG) followed the same trend as the live body weight (LBW). Similar results were obtained by Rupic et al. (1999), Aboul-Ela et al. (2011) and Ali et al. (2011) who found that different proportion up to $28 \%$ olive cake pulp inclusion in rabbit's diets had no adverse effects on final body weight and daily weight gain.

Daily feed intake (DFI) did not differ significantly among treatments (Table 3). Averages of DFI during the whole experimental period (6-14week) were $102.7,93.2,106.5$ and 102.1 for $\mathrm{C}, \mathrm{L}, \mathrm{M}$ and $\mathrm{H}$ groups, respectively. The L group tended to be lower in DFI compared with other groups. These results were in agreement with those reported by Abou-Ela et al. (2011) who found that averages of DFI were 101.6, 102.6,93.63,104.8 and 105 for rabbits fed diets containing $0,7,14,21$ and $28 \%$ olive cake meal for eight wk (from 5-13 wk).

Feed conversion efficiency during the whole experimental period (6-14 wk) was the best in $\mathrm{H}$ group (4.27) followed by L group (4.41) while C and $M$ groups had similar means 4.58 and 4.54 (Table 3). Similar results were obtained by Rupic et al. (1999) who found that rabbits fed diet containing $20 \%$ olive cake had the best feed conversion while those fed diet containing no olive cake had the lowest. In the contrast, Ali et al. (2011) observed that feed conversion of rabbits fed diet containing $22 \%$ OK was lower $(\mathrm{P}<0.05)$ than that fed basal diet.

Table 3. Growth performance and feed efficiency of growing New Zealand White rabbits as affected by dietary level of olive cake pulp.

\begin{tabular}{lllll}
\hline \multirow{2}{*}{ Item } & \multicolumn{4}{c}{ Dietary Treatment } \\
\cline { 2 - 5 } & C & L & M & H \\
\hline
\end{tabular}

Live body weight $(\mathrm{g})$

$\begin{array}{lcccc}6 \mathrm{wk} & 715 \pm 50 & 714 \pm 51 & 715 \pm 50 & 715 \pm 50 \\ 10 \mathrm{wk} & 1544 \pm 82 & 1421 \pm 87 & 1556 \pm 69 & 1605 \pm 91\end{array}$

$\begin{array}{lllll}10 \mathrm{wk} & 1544 \pm 82 & 1421 \pm 87 & 1556 \pm 69 & 1605 \pm 91\end{array}$

\begin{tabular}{lllll}
$14 \mathrm{wk}$ & $1982 \pm 94$ & $1908 \pm 67$ & $2064 \pm 118$ & $2116 \pm 68$ \\
\hline
\end{tabular}

Total weight gain $(\mathrm{g})$

$\begin{array}{lllll}6-10 w k & 820 \pm 69 & 698 \pm 49 & 808 \pm 61 & 829 \pm 58 \\ 10-14 \mathrm{wk} & 438 \pm 35 & 487 \pm 64 & 506 \pm 54 & 511 \pm 58\end{array}$

\begin{tabular}{lllll}
$6-14 \mathrm{wk}$ & $1257 \pm 91$ & $1185 \pm 50$ & $1314 \pm 113$ & $1339 \pm 71$ \\
\hline
\end{tabular}

Daily weight gain (g)

\begin{tabular}{lllll}
\hline $6-10$ wk & $29.2 \pm 2.5$ & $24.9 \pm 1.8$ & $28.9 \pm 2.2$ & $29.6 \pm 2.1$
\end{tabular}

$\begin{array}{lllll}10-14 \mathrm{wk} & 15.7 \pm 1.3 & 17.4 \pm 2.3 & 19.2 \pm 1.7 & 18.2 \pm 2.1\end{array}$

\begin{tabular}{lllll}
$6-14 \mathrm{wk}$ & $22.5 \pm 1.7$ & $21.2 \pm 0.9$ & $23.5 \pm 2.0$ & $23.9 \pm 1.3$ \\
\hline
\end{tabular}

Feed intake g/h/d

6-10 wk $\quad 105.8 \pm 9.8 \quad 91.5 \pm 5.5 \quad 108.3 \pm 16.698 .7 \pm 11.4$

$\begin{array}{lllll}10-14 \mathrm{wk} & 99.6 \pm 7.6 & 95.0 \pm 7.7 & 104.7 \pm 9.3 & 105.6 \pm 5.6\end{array}$

\begin{tabular}{lllll}
$6-14 \mathrm{wk}$ & $102.7 \pm 5.9$ & $93.2 \pm 4.4$ & $106.5 \pm 8.8$ & $102.1 \pm 6.0$ \\
\hline
\end{tabular}

Feed conversion ratio $(\mathrm{g})$

$\begin{array}{lllll}6-10 \mathrm{wk} & 3.42 \pm 0.05^{\mathrm{a}} & 3.67 \pm 0.03^{\mathrm{a}} & 3.75 \pm 0.06^{\mathrm{a}} & 3.33 \pm 0.05^{\mathrm{b}}\end{array}$

$10-14$ wk $\quad 6.37 \pm 0.02^{\mathrm{a}} \quad 5.46 \pm 0.02^{\mathrm{c}} \quad 5.72 \pm 0.06^{\mathrm{b}} 5.79 \pm 0.03^{\mathrm{b}}$

\begin{tabular}{lllll}
$6-14 \mathrm{wk}$ & $4.58 \pm 0.02^{\mathrm{a}}$ & $4.41 \pm 0.01^{\mathrm{b}}$ & $4.54 \pm 0.05^{\mathrm{a}}$ & $4.27 \pm 0.02^{\mathrm{c}}$ \\
\hline
\end{tabular}

\begin{tabular}{lcccc}
\hline No. of dead rabbits & 2 & 2 & 4 & 5
\end{tabular}

\begin{tabular}{lcccc} 
Viability $\%$ & 86.7 & 86.7 & 73.3 & 66.7 \\
\hline a,b,c Means in the same row with different superscripts differ $(\mathbf{P}<\mathbf{0 . 0 5})$.
\end{tabular}

Dietary Treatment; $\mathbf{C}=\mathbf{C}$ Control, containing no OCP; $\mathrm{L}=$ containing $15 \%$ OCP; $M=$ containing $20 \%$ OCP; $H=$ containing $25 \%$ OCP\%.

Viability (V \%):

Viability percentage from 6-14 wk of age decreased gradually with increasing the OCP level in rabbits' diet as shown in Table 3. However, all deaths occurred during the first three wk. These findings are in agreement with those obtained by Abd EL-Galil (2001) who found that mortality rate (MR) of growing rabbits increased gradually with increasing OCP level up to $20 \%$ in rabbits' diet.

\section{Carcass Traits:}

Data in Table 4 showed that OCP inclusion in growing rabbits diets at varying levels (15, 20 and 25\%) did not show any significant effect on all carcass traits (empty carcass with head, total edible parts, head and edible giblets either as weight or percentage of preslaughter weight except edible giblets and liver \%. However, edible giblet and liver \% of rabbits of $\mathrm{H}$ group were lower $(\mathrm{P}<0.05)$ than those of $\mathrm{C}$ but did not differ significantly with those of $\mathrm{L}$ or $\mathrm{M}$ treatment groups. Similarly, Abd EL-Galil (2001) showed nonsignificant differences in carcass traits of rabbits fed either control or $20 \%$ olive pulp meal. Abou-Ela et al. (2011) found that carcass traits as percentage of preslaughter weight did not differ significantly with up to $28 \%$ OKM in rabbits' diets. 
Table 4. Effect of the different levels of olive cake pulp in growing New Zealand White rabbit diets on carcass characteristics.

\begin{tabular}{lcccc}
\hline \multirow{2}{*}{ Item } & \multicolumn{4}{c}{ Dietary Treatment } \\
\cline { 2 - 5 } & $\mathbf{C}$ & $\mathbf{L}$ & $\mathbf{M}$ & H \\
\hline Live-body & $2166.7 \pm 62$ & $2141.7 \pm 62$ & $2116.7 \pm 139$ & $2040.0 \pm 59$ \\
weight (LBW) & & & & \\
Empty carcass & $1359.7 \pm 50$ & $1358.7 \pm 73$ & $1341.7 \pm 132$ & $1271.0 \pm 107$ \\
weight (g) & & & & \\
\% of LBW & $62.8 \pm 0.86$ & $63.4 \pm 0.39$ & $63.5 \pm 1.29$ & $62.3 \pm 3.84$ \\
Total edible & $1443.3 \pm 27$ & $1436.7 \pm 47$ & $1420.0 \pm 85$ & $1338.3 \pm 65$ \\
parts (g) & & & & \\
\% of & $66.7 \pm 0.6$ & $67.07 \pm 0.36$ & $67 \pm 0.54$ & $65.59 \pm 2.37$ \\
LBW(dressing), & & & & \\
Edible giblets & $85.3 \pm 1.2$ & $78.0 \pm 5.86$ & $78.3 \pm 9.21$ & $67.33 \pm 3.76$ \\
(g) & & & & \\
\% of LBW & $3.95 \pm 0.14^{\mathrm{a}}$ & $3.63 \pm 0.17 \mathrm{ab}$ & $3.68 \pm 0.20^{\mathrm{ab}}$ & $3.30 \pm 0.16^{\mathrm{b}}$ \\
Head (g) & $127.7 \pm 11$ & $129.6 \pm 6.89$ & $115.3 \pm 5.36$ & $127.0 \pm 2.65$ \\
\% of LBW & $5.9 \pm 0.41$ & $6.05 \pm 0.18$ & $5.46 \pm 0.11$ & $6.24 \pm 0.29$ \\
Liver(g) & $66.3 \pm 1 . \wedge$ & $60.3 \pm 4.48$ & $61.0 \pm 7.94$ & $51.0 \pm 2.65$ \\
\% of LBW & $3.07 \pm 0.14^{\mathrm{a}}$ & $2.81 \pm 0.13^{\mathrm{ab}}$ & $2.86 \pm 0.20^{\mathrm{ab}}$ & $2.50 \pm 0.13^{\mathrm{b}}$ \\
kidney (g) & $12.7 \pm 0.3$ & $13 \pm 1.15$ & $11.6 \pm 1.20$ & $10.6 \pm 0.67$ \\
\% of LBW & $0.58 \pm 0.03$ & $0.61 \pm 0.04$ & $0.55 \pm 0.02$ & $0.52 \pm 0.02$ \\
Heart (g) & $6.3 \pm 0.9$ & $4.67 \pm 0.33$ & $5.67 \pm 0.33$ & $5.67 \pm 0.67$ \\
\% of LBW & $0.29 \pm 0.04$ & $0.22 \pm 0.01$ & $0.27 \pm 0.02$ & $0.28 \pm 0.03$ \\
\hline ab L
\end{tabular}

${ }^{a, b}$ Means in the same row with different superscripts differ $(\mathrm{P}<0.05)$.

'Dietary Treatment; $C=$ Control, containing no OCP; $L=$ containing $15 \%$ OCP; $M=$ containing $20 \%$ OCP; $H=$ containing $25 \%$ OCP\%.

${ }^{2}$ Total edible parts wt. $=$ empty carcass wt. $($ with head $)+$ edible giblets wt.

Total edible parts $\%=$ total edible parts wt. /fasted wt. * 100

${ }^{3}$ Edible giblets wt. $=$ Liver + Kidneys wt. + Heart wt.

\section{Blood Constituents:}

Blood constituents and metabolites changes could be used as indicator for the nutritional and physiological status of the animal. Data presented in Table 5 showed that all serum constituents were within the normal range (Manning et al., 1994) and that olive cake pulp in the present treatments had no significant effect on most of the selected serum constituents. The insignificant decrease $(\mathrm{P}>.05)$ in serum total protein in $\mathrm{H}$ group and the slightly lower $(\mathrm{P}>.05)$ urea concentration in $\mathrm{L}, \mathrm{M}$ and $\mathrm{H}$ groups than that of $\mathrm{C}$ group could be attributed to lower degradability of protein in olive cake pulp. However, 75 to $90 \%$ of its nitrogen is linked to the lingo-cellulose fraction which are the two main factors limiting the digestive utilization of olive by-products (Aguilera 1987). Sansoucy (1983) found that crude protein digestibility of olive byproduct reaches only 20 to $25 \%$.

Glucose and triglycerides concentrations in serum of rabbits fed diets containing OCP at varying levels ( $\mathrm{L}, \mathrm{M}$ and $\mathrm{H} \%)$ were lower $(\mathrm{P}<0.05)$ than those fed the control diet. The decrease in glucose, triglycerides and cholesterol of rabbits fed diets containing OCP may be linked to the presence of phenolic compounds and saponins in olive cake pulp. Abo-Zaid et al. (1993) found that rats injected with phenolic compounds showed significantly lower total lipids, triglycerides, phospholipids and cholesterolPlasma glucose and urea levels showed a fluctuation response due to the same treatment. The same authors found an increase in liver enzymes (AST and ALT) as well as alkaline phosphate (Ap) in rats treated with phenolic compounds compared with untreated ones. Also, saponins are known to bind with bile acids and cholesterol, thereby such compounds can purge these fatty compounds from the body and consequently decrease blood cholesterol (Michael, 2005). In addition, Leto and Giaconne (1981) found that oleic acid was greater and myristic, plamitic, stearic, linoleic and linolenic acids were lower in perirenal fat of rabbits fed olive cake than those fed the control diet. Similary, ELKardawy (1997) found that cholesterol and total lipids decreased $(\mathrm{P}<0.01)$ in blood serum of rabbits given olive pulp at 10 and $15 \%$ of the diet compared with those given the control or olive pulp at $5 \%$ level.

The insignificant effects of dietary treatments on most serum constituents may be attributed to the adequacy of nutrients especially crude protein in all the experimental diets.

Table 5.Effect of the different levels of olive cake pulp in growing New Zealand White rabbits' diets on some blood constituents.

\begin{tabular}{|c|c|c|c|c|}
\hline \multirow{2}{*}{ Items } & \multicolumn{4}{|c|}{ Dietary Treatment ${ }^{*}$} \\
\hline & $\mathbf{C}$ & $\mathbf{L}$ & $\mathbf{M}$ & H \\
\hline $\begin{array}{l}\text { Total protein } \\
(\mathrm{g} / \mathrm{dl})\end{array}$ & $6.47 \pm 0.39$ & $6.55 \pm 0.15$ & $6.33 \pm 0.40$ & $5.83 \pm 0.10$ \\
\hline $\begin{array}{l}\text { Albumin } \\
(\mathrm{g} / \mathrm{dl})\end{array}$ & $3.70 \pm 0.16$ & $3.50 \pm 0.15$ & $3.70 \pm 0.12$ & $3.58 \pm 0.11$ \\
\hline $\begin{array}{l}\text { Globulin } \\
(\mathrm{g} / \mathrm{dl})\end{array}$ & $2.76 \pm 0.26$ & $3.06 \pm 0.25$ & $2.63 \pm 0.48$ & $2.25 \pm 0.21$ \\
\hline $\begin{array}{l}\text { Alb/ } \\
\text { Glo }\end{array}$ & $1.35 \pm 0.08$ & $1.16 \pm 0.13$ & $1.53 \pm 0.36$ & $1.64 \pm 0.23$ \\
\hline $\begin{array}{l}\text { Glucose } \\
\text { (mg/dl) }\end{array}$ & $116.30 \pm 18.98^{\circ}$ & $65.67 \pm 7.88^{\mathrm{b}}$ & $72.00 \pm 6.66^{\mathrm{b}}$ & $76.33 \pm 7.36^{\mathrm{b}}$ \\
\hline $\begin{array}{l}\text { Cholesterol } \\
(\mathrm{mg} / \mathrm{dl})\end{array}$ & $63.67 \pm 19.37$ & $49.67 \pm 14.17$ & $44.33 \pm 9.24$ & $40.33 \pm 10.33$ \\
\hline $\begin{array}{l}\text { Triglycerides } \\
(\mathrm{mg} / \mathrm{dl})\end{array}$ & $59.00 \pm 6.66^{\mathrm{a}}$ & $33.67 \pm 3.48^{\mathrm{b}}$ & $28.33 \pm 5.61^{\mathrm{b}}$ & $46.33 \pm 10.73^{\mathrm{ab}}$ \\
\hline $\begin{array}{l}\text { Urea } \\
(\mathrm{mg} / \mathrm{dl})\end{array}$ & $30.33 \pm 2.33$ & $23.33 \pm 4.67$ & $22.67 \pm 1.86$ & $25.67 \pm 5.46$ \\
\hline $\begin{array}{l}\text { Creatinine } \\
(\mathrm{mg} / \mathrm{dl})\end{array}$ & $1.50 \pm 0.06$ & $1.17 \pm 0.10$ & $1.38 \pm 0.15$ & $1.36 \pm 0.11$ \\
\hline AST (U/L) & $61.00 \pm 5.69$ & $49.67 \pm 3.28$ & $55.33 \pm 11.20$ & $43.67 \pm 6.77$ \\
\hline ALT (U/L) & $35.67 \pm 2.40^{\mathrm{ab}}$ & $41.00 \pm 4.16^{\mathrm{a}}$ & $40.67 \pm 5.78^{\mathrm{a}}$ & $26.00 \pm 0.58^{\mathrm{b}}$ \\
\hline
\end{tabular}

Economic Efficiency:

Feed cost $/ \mathrm{kg}$ gain, net revenue (NR), economic efficiency (EE) and relative economic efficiency (REE) are listed in Table 6. It is evident that the lower price of OCP is reflected on the price of the experimental diets. Feeding growing rabbits on diets containing 15, 20 and $25 \%$ OCP decreased the feed cost $/ \mathrm{kg}$ gain by $9.11,7.25$ and $14.32 \%$ while net revenue values were increased with OCP inclusion by 5.83, 15.73 and 23.62\%, respectively compared with those fed the control diet. It was clear that the economic efficiency $(\mathrm{EE} \%)$ and relative economic efficiency (REE\%) were highest with the diet containing 25\% OCP followed by those containing 15 and $20 \%$ OCP compared with the control diet. These results were in agreement with those obtained by Abdel-Naby (1998), EL-Lathy (2001), ELSayed (2010) and Abdel- Shafi (2015). 
Table 6. Economic efficiency as affected by olive cake pulp inclusion in rabbits' diet.

\begin{tabular}{|c|c|c|c|c|}
\hline \multirow{2}{*}{ Item } & \multicolumn{4}{|c|}{ Dietary Treatment" } \\
\hline & $\mathbf{C}$ & $\mathbf{L}$ & M & $\mathbf{H}$ \\
\hline Price/kg diet & 2.44 & 2.30 & 2.28 & 2.24 \\
\hline $\begin{array}{l}\text { Total feed } \\
\text { intake/rabbit }(\mathrm{g})\end{array}$ & 5751 & 5221 & 5966 & 5719 \\
\hline $\begin{array}{l}\text { Total feed cost/rabbit } \\
\text { (L.E) }\end{array}$ & 14.03 & 12.01 & 13.6 & 12.81 \\
\hline $\begin{array}{l}\text { Total weight } \\
\text { gain/rabbit(gm) }\end{array}$ & 1256.87 & 1185 & 1313.57 & 1339.28 \\
\hline Feed cost $/ \mathrm{kg}$ gain & 11.17 & 10.13 & 10.36 & 9.57 \\
\hline $\begin{array}{l}\text { Price/kg weight gain } \\
\text { (L.E) }\end{array}$ & 27 & 27 & 27 & 27 \\
\hline $\begin{array}{l}\text { Total revenue/weight } \\
\text { gain(L.E) }\end{array}$ & 33.91 & 31.99 & 35.45 & 36.15 \\
\hline Net revenue/rabbit (L.E) & 18.88 & 19.98 & 21.85 & 23.34 \\
\hline $\begin{array}{l}\text { Economic efficiency } \\
\text { (E.E) }\end{array}$ & 1.34 & 1.66 & 1.61 & 1.82 \\
\hline Relative E. E (\%) & 100 & 123.88 & 120.14 & 135.82 \\
\hline
\end{tabular}

\section{CONCLUSION}

It could be concluded that the use of by-products is necessary to reduce the price of feed, because feed cost is one of the main obstacles to the development of rabbit production. Therefore, olive cake pulp (OCP) could be used in feeding growing rabbits up to $15 \%$ and $25 \%$ of the diet during 6-9 and 9-14 wk of age, respectively with no adverse effects on growth performance, physiological status, carcass traits. In addition, due to the lower prices of olive cake pulp compared to traditional feeds, the economic efficiency could be increased when using it as a substitute.

\section{REFERENCES}

A.O.A.C. (2012) Association of Official Analatical Chemists. Official methods of analysis. $19^{\text {th }} \mathrm{Ed}$. A.O.A.C. Washington. DC, USA.

Abd EL-Galil, K. (2001). Utilization of olive pulp meal in feeding growing rabbits. J. of Agriculture Sci. Mansoura University 26; 727-736.

Abd El-Maksoud, A. (2011). Effect of biologically treated Jojoba meal by (Aspergillusfunigotus) on performance of growing rabbits. Egyptian J. of rabbit Sci., 21 (2) 165-180.

Abdel-Naby, M. R. (1998). Evolution of olive cake as waste product of feed industry in rabbits. M. SC. Thesis, Fac. of Agriculture, Zagazig University. Egypt.

Abdel-Samee, A. M.; A. M. Ali; M.R.M. Mousa and M. A. Abdel Ghaffar (2003). Performance of heat stressed New Zealand white (NZW) growing rabbits in subtropics. Egyptian J, Nutrition and feeds 6; 221229.

Abdel-Shafi, Amira A. (2015). Effect of Agro-industrial byproducts on reproductive performance of rabbits under North Sinai conditions.M.SC. Thesis College of Environmental Agricultural Sciences, Arish University, Egypt.
Aboul-ELa, S.S; F.A.F. Ali; A. Madi and M.R.A. ELNaby (2011). Olive cake meal as partial or complete substitute for clover hay in growing rabbit diets. Egyptian Journal of Nutrition and Feeds. 14; 109-119.

Abo-Zaid, M. A.; Farag, S.E. A. and Saad, M. (1993). Identification and purification of the phenolic compounds extracted from olive cakes. Egyptian Journal of applied science. 8(6): 791-802.

Agriculture Ministry Decree (1996). The Standard Properties for Ingredients, Feed Additives and Feed Manufactured for Animal and Poultry. El-Wakaee

Aguilera, J.F. (1987). Improvement of olive cake and grape by products for animal nutrition. Proceeding of a workshop held in lelystad. Netherlands.

Ali, F. A. F.; S. S. AbouEla; A. Mahdi and M. R. Abd ELNaby (2011). Effect of olive cake substitution of wheat bran in the feed mixtures of growing New Zealand and rabbits. Egyptian Journal of Nutrition and feeds; 14: 99-108.

Cheeke, P. R. (1987). Rabbit feeding and nutrition. Academic press. Ozlanda, Flarida, U. S. A.

Duncan, D. B. (1955). Multiple range and multiple F tests. Biometrics 11:1-42.

EL-Kardawy, D. M.A (1997). Olive pulp as A New Energy source for growing rabbits Egyptian Journal of rabbits Science 7 (1): 1-12.

EL-Lathy A. A. M (2001). Use of some by products in rabbit diets. Thesis PH. D. Department of Animal production, Faculty of Agriculture Zagazig University, Egypt.

El-Sayed, A. S. S. (2010). Unconventional feed in rabbit Nutrition. Ph. D thesis, Fac. Veterinary Medicine, Zagazg University, Egypt.

Ghazalah, A. A. and EL-Shaat, A. A. (1994) Digestibility and acceptability of some agro-industrial byproducts by rabbits. J. of Egyptian Poultry Science, $14 ; 401-422$.

Gu, Z.L (2002). Modern Rex Rabbit production, Heli Science and Technology press, Shijiazhuang, China.

Leto, G and Giaccone, P. (1981). Testing olive cake utilization in rabbit nutrition. Italian ZootechnicaNutrizione Animal 7: 184-192.

Manning, P. J.; D. H. Ringler and C. E. New comer (1994). The Biology of the laboratory rabbit, $2^{\text {nd }}$ ed. Academic press Inc., San Diego, California, u. s. a.

Mehrez, A.Z. and M.R.M. Mousa (2011) Growth performance of rabbits fed olive pulp in North Sinai, Asian Journal of Animal Production Science. 5 (5): 317-329.

Michael, W. D. (2005). Saponin. The Florida State University,

MOA (2001). Feed composition tables for Animal and Poultry feed stuff used in Egypt. Technical Bulletin No.1, central Lab for feed and food, Ministry of Agriculture, Egypt.

North Sinai governorate (2000). Information center of North Sinai governorate, Egypt.

Rabayaa, E.; Abo Omar, J. M. and Othman, R.A (2001) Utilization of olive pulp in broiler rations. An Najah Univ. J. Res. 15. 134-143. 
Rupic, V., J. Skrlini; S. Muzic; v. Serman; N. Stipic ; and L. Bacar-Huskic (1999). Protein and fats in the serum of rabbits fed different quantities of dried olive cake. Acta vet. Brno, 86: 91-98.

Sansoucy, R. (1983). Olive by-products for animal feed .FAO. Animal Production and Health paper food and agriculture organization of the United Nations.
SPSS (2007). User's guide: statistics. Version 16. SPSS Inc. Chicago, IL, USA.

V. Christodoulou, V. A. Bampidis, C. J. Israilides P. H. Robinson, A. Giouzelyiannis and A. Vlyssides (2008). Nutritional value of fermented olive wastes in growing Lamb rations. Animal feed science and technology. 141, 273-383.

\section{تأثير الإحلال الجزئى أو الكلى لتفل الزيتون محل نخالة القمح فى علائق الأرانب النامية على الأداء الإنتاجى وصفات

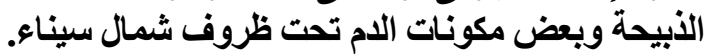

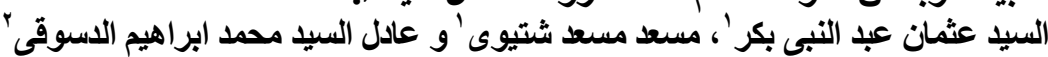

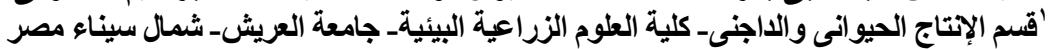

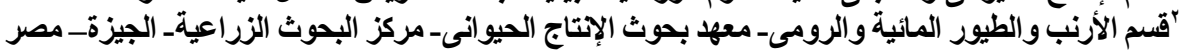

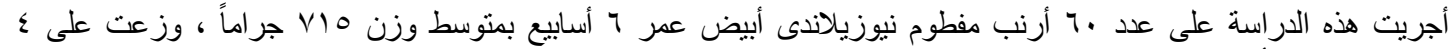

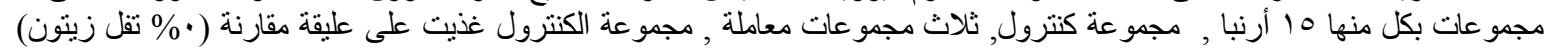

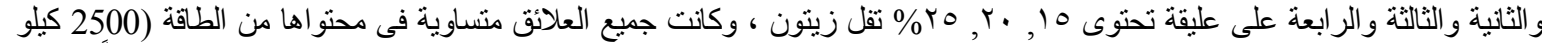

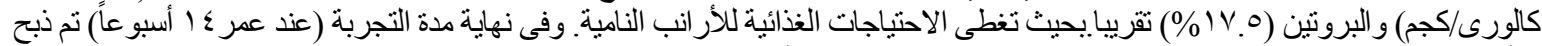

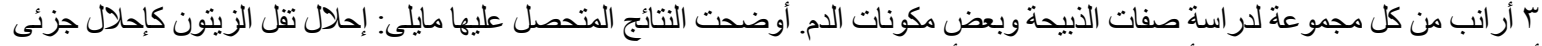

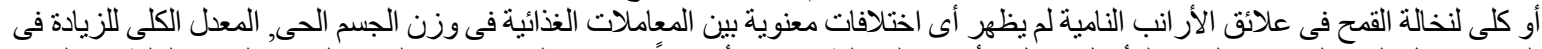

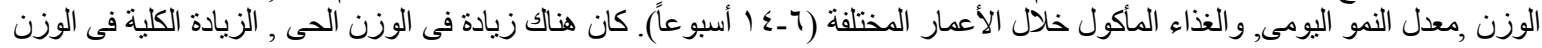

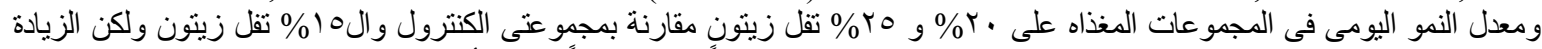

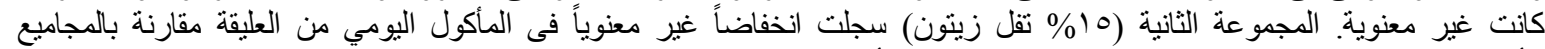

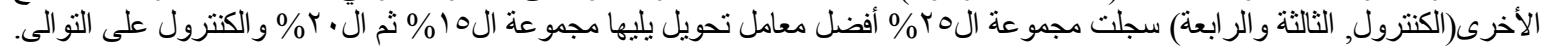

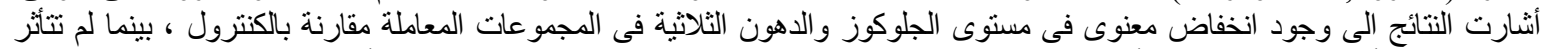

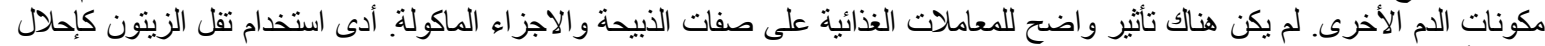

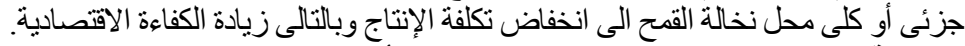

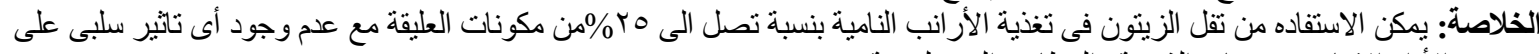

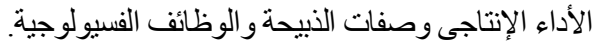

